\title{
PENGARUH WORK-LIFE BALANCE TERHADAP KINERJA KARYAWAN YANG DIMEDIASI OLEH KOMITMEN AFEKTIF
}

\author{
Asima \\ Levi Nilawati \\ Universitas Katolik Atmajaya \\ asima.nurani@gmail.com
}

\begin{abstract}
This study examined the relationship between work life balance on the performance. This research also examined the mediating role of affective commitment in a retail company in Jakarta. To find answers to these problems researchers distribute a questionnaire consisting of 10 questions about work life balance, six questions about affective commitment, and 11 questions about the performance of employees to 50 employees. The sampling method used is convenience sampling. The data were processed using path analysis with statistical methods SPSS 17.0 for Windows. Based on the results obtained path analysis, it can be concluded that the affective commitment does not mediate the relationship between work life balance to employee performance, but the direct effect proved.
\end{abstract}

Keyword: affective commitment, performance, work life balance

\section{PENDAHULUAN}

Sukses, seimbang dan berjalan dengan selaras didalam pekerjaan, kehidupan pribadi dan sosial merupakan tujuan utama seseorang dalam meraih aktualisasi diri terhadap potensi yang dimiliki. Banyak peneliti yang secara umum setuju dengan betapa penting peran dari work-life balance dimana hal tersebut berhubungan dengan kesejahteraan psikologis secara individual dan secara menyeluruh dalam keharmonisan di kehidupan, yang merupakan indikator dari keseimbangan antara peran kerja dan peran di keluarga (Marks \& MacDermid, dalam Clark, 2000). Work-life balance didefinisikan sebagai kepuasan dan berfungsi dengan baik di tempat kerja dan di rumah, dengan konflik peran yang minimum (Clark, 2000, p.751a). Mengelola work-life balance telah menjadi salah satu strategi manajerial yang paling penting untuk memastikan kinerja karyawan dan peningkatan kinerja organisasi, hal ini dibuktikan dengan penelitian baru-baru ini menunjukan manfaat bagi kedua belah pihak yakni pekerja dan organisasi dari kesuksesan keseimbangan kerja dan kehidupan keluarga (Greenhaus and Powell, 2006; Hammer et al., 2005). Work-life balance telah terbukti memiliki hasil positif seperti menurunnya keinginkan untuk pindah, peningkatan kinerja, dan kepuasan kerja (e.g., Cegarra-Leiva et al. ; Nelson et al. ; Scandura \& Lankau, 1997 dalam Kim,2014). Tidak adanya work-life balance menyebabkan kinerja karyawan yang buruk dan seringnya ketidakhadiran karyawan (Frone et al., 1997). Dalam lingkungan keluarga, ketika orang mengalami ketidakseimbangan antara kehidupan pribadi dan pekerjaan, akan mengancam area utama kehidupan mereka. Selain itu kurangnya perhatian perusahaan terhadap work-life balance menyebabkan orang mencari cara memenuhi kebutuhan masing-masing, dimana hal ini seringkali bertentangan dengan kepentingan 
kolektif dan menyebabkan terganggunya interaksi sosial.

Dengan perubahan lingkungan dan nilai-nilai pekerja, keinginan karyawan akan keseimbangan hidup dan pekerjaan terus meningkat dan orang atau perusahaan yang mempekerjakan memberi reaksi pada apa yang dibutuhkan para karyawan mereka dengan memberikan sejumlah tawaran tambahan yang dirasa cukup untuk mempertahankan kinerja karyawannya (Thornthwaite, 2004). Didalam daftar 100 perusahaan tempat bekerja terbaik, majalah Fortune mengidentifikasi organisasiorganisasi tersebut berusaha membantu karyawannya dalam mengelola tanggung jawab kerja dan keluarga (Muse et al., 2008). Beberapa penelitian empiris telah menunjukkan bahwa dalam tataran praktis, work-life balance berhubungan positif dengan kinerja karyawan dan juga kinerja organisasi (Harrington dan Ladge, 2009).

Dengan terciptanya work-life balance, organisasi mengharapkan agar setiap karyawan memiliki komitmen terhadap organisasi. Komitmen organisasional adalah suatu nilai personal, dimana seringkali komitmen organisasional mengacu kepada loyalitas terhadap perusahaan atau komitmen terhadap perusahaan (Cherrington, 1994). Menurut Allen dan Meyer (1997), Terdapat tiga komponen komitmen, yakni komitmen sebagai suatu ikatan atau hubungan afektif (affective attachment) pada organisasi, komitmen sebagai suatu biaya yang dirasakan (perceived cost) yang berhubungan dengan meninggalkan organisasi (continuence commitment), dan komitmen sebagai suatu kewajiban untuk tetap bertahan dalam organisasi (normative commitment).

Kinerja merupakan suatu potensi yang harus dimiliki oleh setiap karyawan untuk melaksanakan setiap tugas dan tanggung jawab yang diberikan perusahaan kepada karyawan secara efektif dan efisien, sehingga setiap konflik dan tantangan yang terjadi di dalam organisasi dapat teratasi dengan baik "di ukur dari periode waktu tertentu" (Bernardin \& Russell, 1993, p. 135). Kinerja yang baik dapat diukur saat karyawan merealisasikan visi dan misi organisasi sesuai dengan kesepakatan bersama antara karyawan dan organisasi dalam mewujudkan tujuan perusahaan. Ada hubungan positif antara komitmen organisasional dan produktivitas kerja, pada umumnya tampak bahwa komitmen afektif memiliki hubungan yang lebih erat dengan hasil organisasi seperti kinerja dan perputaran karyawan bila dibandingkan dengan dua dimensi komitmen lain. Penelitian sebelumnya menemukan bahwa komitmen afektif memprediksi berbagai hasil (persepsi karakteristik tugas, kepuasan karier, niat untuk pergi) dalam 72 persen kasus, dibandingkan dengan hanya 36 persen untuk komitmen normatif dan 7 persen untuk komitmen berkelanjutan (Robbins, 2008). Karyawan yang berkomitmen rendah akan berdampak pada turnover, tingginya absensi, meningkatnya kelambatan kerja dan kurangnya intensitas untuk bertahan sebagai karyawan, rendahnya kualitas kerja dan kurangnya loyalitas pada perusahaan (Streers, 1991 dalam Sopiah 2008).

Menurut Kim (2014), bahwa work-life balance memiliki peran penting yang signifikan dengan kesejahteraan psikologis (psychological well-being) yang didefinisikan sebagai sejauh mana seorang individu memiliki tujuan dalam hidupnya, apakah mereka menyadari potensipotensi yang dimiliki, kualitas hubungannya dengan orang lain, dan sejauh mana mereka merasa bertanggung jawab dengan hidupnya sendiri (Ryff \& Keyes, 1995, p. 725) dan perilaku kinerja. Penelitian ini juga mengemukakan bahwa work-life balance bersama dengan komitmen afektif dapat mempengaruhi kemajuan kinerja karyawan pada karyawan di Korea, worklife balance meningkat dan penelitian lebih mendalam tentang work-life balance dibutuhkan. Zimbardo (dalam Kim, 2014), ketika emosi 
dibangkitkan, emosi mengarah kepada tindakan. Ini memungkinkan karyawan berkomitmen secara afektif kepada organisasi, maka emosi memotivasi perilaku karyawan. Dengan melihat dampak positif komitmen afektif terhadap kinerja karyawan, maka peneliti bermaksud untuk meneliti kembali pengaruh work-life balance terhadap kinerja karyawan dengan peran komitmen afektif sebagai variabel mediasi.

\section{REVIEW LITERATUR DAN HIPOTESIS}

\section{Work-Life Balance dan Komitmen Afektif}

Work-life balance dijelaskan melalui dua ranah yaitu ranah kerja (work) dan non-kerja. Work atau kerja merujuk kepada sekelompok tugas yang dilaksanakan oleh individu pada saat menduduki sebuah posisi di organisasi dan nonkerja merujuk pada aktivitas dan tanggung jawab dalam keluarga (Geurts \& Demerouti, 2003). Guest (2002), memberikan definisi yang lebih luas dimana non-kerja didefinisikan sebagai aktivitas diluar pekerjaan. Aktivitas di luar pekerjaan ini juga dapat meliputi waktu bebas dimana individu tidak memperoleh tuntutan dari orang lain. Selain waktu bebas, non-kerja juga dapat meliputi waktu luang (leisure), individu melakukan aktivitas tertentu di luar pekerjaan. Setiap ranah mempunyai tuntutan kepada individu, yaitu dapat menyeimbangkan perannya dalam ranahnya. Kalliath dan Brough (2008) mendefinisikan worklife balance sebagai persepsi individu bahwa aktifitas kerja dan non-kerja harus sepadan dan mendorong pertumbuhan sesuai dengan prioritas hidup individu saat ini. Keseimbangan antar ranah mengarah pada pertumbuhan dan perkembangan positif dalam aktivitas kerja (seperti, memperoleh pengakuan kerja dan potensi karir) dan/atau nonkerja (seperti, melakukan perjalanan, mengurus anak dan kehidupan pribadi).

Fisher (2001) mendefinisikan work-life balance sebagai stressor yang terkait dengan pekerjaan yang meliputi empat isu, yaitu waktu, energi, pencapaian tujuan, dan ketegangan. Waktu merujuk kepada jumlah waktu yang dihabiskan untuk bekerja, dibandingkan denganjumlah waktu yang dihabiskan untuk terlibat dalam aktivitas lain. Ketegangan meliputi kecemasan, tension (ketegangan), meninggalkan aktivitas penting dalam kehidupan dan kesulitan dalam atensi. Terdapat dua manfaat work-life balance menurut (Byrne, 2005), yaitu (a) manfaat bagi perusahaan, seperti meningkatkan produktifitas, mengurangi tingkat absensi, memaksimalkan tersedianya tenaga kerja, dan mengurangi biaya. (2) manfaat bagi karyawan, seperti agar karyawan memiliki tanggung jawab dan rasa memiliki yang lebih besar terhadap perusahaan, memiliki hubungan yang lebih baik dengan perusahaan, lebih baik dalam mengontrol kehidupan pekerjaannya, dan karyawan tidak membawa masalah keluarganya ke dalam pekerjaan.

Dalam congruence model menjelaskan tentang konsep hubungan antara work-life balance dan kinerja karyawan. Bagaimanapun, congruence model percaya bahwa adanya pengaruh variable ketiga untuk melihat adanya domain kerja dan diluar kerja, seperti kepribadian, faktor genetis, sosial dan budaya. Salah satu contoh spesifik dari variabel yang mengarah kepada congruence model adalah afeksi negatif. Afeksi negatif merupakan disposisi pribadi seseorang yang cenderung menilai suatu hal dengan cara negatif(Watson, Clark, \& Tellegen, dalam Fisher, 2001). Misal, jika seseorang sering mengalami ketidakpuasan atas pekerjaan dan kehidupan pribadinya maka hal itu membuat seseorang memiliki disposisi yang kuat akan afeksi negatif, dan akan mempengaruhi persepsinya pada dua domain tersebut. Menurut Schabracq, Winnubst, dan Cooperr (2003) ada beberapa faktor yang mempengaruhi work-life balance seseorang, yaitu karakteristik, kepribadian, keluarga, pekerjaan, 
dan sikap. Kebanyakan karakteristik kepribadian memiliki pengaruh terhadap kehidupan kerja dan di luar lingkungan kerja seperti neuroticism, extraversion, personal coping, dan kepribadian tipe A. Selain itu, Surner dan Knight (2001) juga menyatakan bahwa terdapat hubungan antara tipe attachment yang didapatkan individu ketika masih kecil dengan work-life balance. Individu yang memiliki secure attachment cenderung mengalami positif spillover dibandingkan individu yang memiliki insecure attachment, adanya peningkatan salah satu domain kehidupan karena merupakan hasil dari pengaruh domain lain.

Karakteristik Keluarga, salah satu aspek yang menjadi penyebab terjadinya konflik antara pekerjaan dan di dunia luar kerja adalah situasi yang terjadi dalam keluarga. Misalnya, konflik peran yang terjadi dalam keluarga dan ambiguitas peran dalam keluarga (tidak jelas yang menjadi keharusan dalam keluarga). Karakteristik Pekerjaan, jumlah waktu yang dihabiskan untuk bekerja (misalnya pola jam kerja dalam satu minggu, kerja satu hari atau paruh waktu dan bekerja hampir setiap waktu) dapat mempengaruhi konflik yang terjadi antara domain kerja dan keluarga (Greenhaus \& Beutell dalam Schabracq, Winnubst, \& Cooper, 2003).

Menurut Undang-undang Nomer 13 Tahun 2003 tentang ketenagakerjaan, Pasal 77, dalam satu hari karyawan bekerja 7 jam/hari untuk yang bekerja 6 hari dalam satu minggu dan 8 jam/hari untuk yang bekerja 5 hari dalam satu minggu, sehingga di Indonesia karyawan bekerja rata-rata 40-42 jam/minggu. Menurut Valcour (2007), jumlah jam kerja akan mempengaruhi kepuasan seseorang akan keseimbangan dalam kehidupan pekerjaan dan kehidupan di luar pekerjaannya. Sikap, adanya asumsi dasar bahwa sentralitas terhadap suatu domain tertentu dalam kehidupan individu, meningkatkan jumlah waktu dan usaha yang dihabiskan dalam domain tersebut keluarga (Greenhaus \& Beutell dalam Schabracq, Winnubst, \& Cooper, 2003). Hal ini membuat individu kesulitan menyediakan waktu dan ikut serta pada domain lain (Frone, dalam Schabracq, Winnubst, \& Cooper, 2003).

Karyawan yang memiliki komitmen terhadap organisasi memiliki hasrat untuk tetap tinggal dan mengabdikan diri sepenuhnya dan membantu perusahaan dalam mengwujudkan tujuannya. Komitmen dalam berorganisasi didefinisikan sebagai suatu konstruk psikologis yang merupakan karakteristik hubungan anggota dengan organisasinya dan memiliki implikasi terhadap keputusan individu untuk melanjutkan keanggotaannya dalam berorganisasi (Meyer \& Allen, 1991). Noe (2001), komitmen diartikan sebagai tingkat dimana karyawan mengidentifikasikan dirinya bersama dengan organisasi, dan memberikan upaya untuk pencapaian tujuan organisasi. Komitmen organisasi bukan hanya kesetiaan karyawan terhadap perusahaan saja, namun juga kesediaan karyawan dalam berupaya mencapai tujuan utama organisasi, dan anggota yang memiliki komitmen terhadap organisasi akan lebih dapat bertahan sebagai bagian dari organisasi dibandingkan anggota yang tidak.

Schermerhorn, Osborn, Uhl-Bien dan Hunt (2011), terdapat dua dimensi komitmen organisasi, yaitu komitmen rasional dan emosional. Komitmen rasional merupakan perasaan bahwa pekerjaan memberikan penghasilan pengembangan dan kebutuhan profesional. Komitmen emosional adalah perasaan bahwa apa yang dikerjakan seseorang adalah sangat penting, berharga dan sangat menguntungkan orang lain. Sedangkan Allen dan Meyer (dalam Robbins \& Judge, 2008), mengatakan bahwa komitmen organisasi terdiri dari 3 dimensi, yaitu (a) affective 
commitment (komitmen afektif), merupakan keterikatan emosional terhadap organisasi dan kepercayaan terhadap nilai organisasi. (b) continuance commitment (komitmen berkelanjutan), merupakan penerimaan manfaat ekonomi karena bertahannya seorang karyawan menjadi anggota organisasi. Seorang karyawan memiliki komitmen terhadap organisasi yang memperkerjakannya karena organisasi tersebut telah membayarnya dengan cukup. Dia merasa keluarganya akan sengsara hidupnya jika keluar dari organisasi tersebut. Dan (c) normative commitment (Komitmen normatif), merupakan suatu keharusan untuk tetap menjadi anggota organisasi karena alasan moral atau alasan etika. Seorang karyawan merasa ingin tetap bertahan menjadi anggota suatu organisasi karena dia merasa bahwa akan mengalami kesulitan jika dia meninggalkan organisasi.

Gambar 1 menggambarkan bagaimana ketiga dimensi tersebut membentuk keterikatan psikologis yang membentuk komitmen organisasi. Pada gambar dapat diketahui bahwa seorang karyawan tidak hanya berkomitmen terhadap organisasinya, tetapi juga berkomitmen terhadap pimpinannya, divisi kerjanya, manajernya, kelompok kerjanya atau teman sejawatnya. Ketiga komitmen, yaitu komitmen afektif, komitmen berkelanjutan, dan komitmen normatif membentuk suatu keterikatan psikologis terhadap organisasi yang disebut dengan komitmen organisasi. Karyawan yang berbeda mungkin memiliki tipe komitmen organisasi yang berbeda. Masing-masing karyawan akan memiliki prioritas tipe komitmen organisasi sesuai dengan alasan yang melatarbelakangi komitmennya terhadap organisasi. Jika karyawan tersebut memprioritaskan ketiga tipe komitmen organisasi tersebut, maka semakin kuat komitmennya terhadap organisasi.

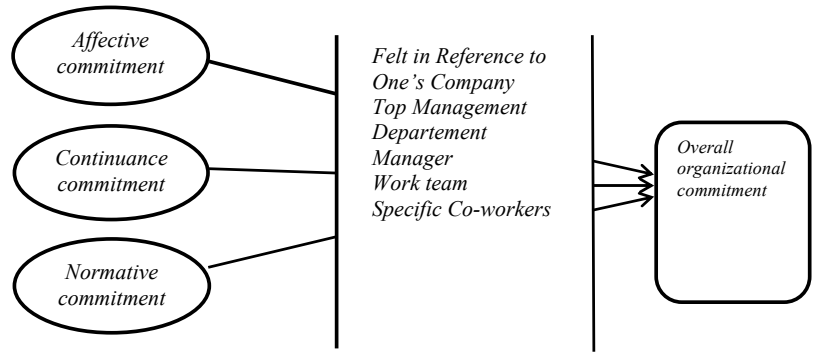

Sumber: Colquitt, LePine dan Wesson dalam Organizational Behaviour: Improving Performance and Commitment in The Workplace, 2011

\section{Gambar 1}

Drivers of Overall Organizational Commitment

Menurut Colquitt, LePinne dan Wesson (2009)terdapatduahalyangmembentukkomitmen organisasi karyawan, yaitu (a) keanekaragaman tenaga kerja (diversity of the workforce), yang kemudian membentuk kelompok-kelompok berdasarkan ras, jenis kelamin, usia, atau suku bangsa dapat mengancam pihak-pihak minoritas atau karyawan yang berusia lanjut berada di luar kelompok tersebut. (b) Perubahan hubungan karyawan dengan pemberi kerja (changing employee-employer relationship), seperti pengurangan karyawan memberikan dampak terhadap karyawan lain, dimana akan terdapat pandangan bahwa hal tersebut dapat terjadi pada mereka (downsizing syndrome).

Kim (2014) melakukan penelitian untuk melihat pengaruh work-life balance terhadap afektif komitmen dan in-role performance, dan untuk mengetahui apakah mediasi komitmen afektif berperan untuk menghubungkan work-life balance dan in-role performance. Hasil penelitian menunjukkan tidak ada pengaruh langsung worklife balance terhadap in-role performance, tetapi ditemukan bahwa karyawan yang merasakan work-life balance akan meningkatkan komitmen afektif.

$\mathbf{H}_{\mathbf{1}}$ : Work-life balance berpengaruh terhadap komitmen afektif. 


\section{Komitmen Afektif dan Kinerja Karyawan}

Employee retention merupakan upaya perusahaan untuk mempertahankan karyawan. "People who are committed are less likely to quit and accept other jobs" (Freund dalam Ivancevich, Konopaske dan Matteson, 2008) yang diartikan yakni seseorang yang berkomitmen tidak menyukai berhenti dari pekerjaannya dan menerima pekerjaan lainnya. Komitmen organisasi mempengaruhi apakah karyawan tetap bertahan sebagai anggota organisasi atau meninggalkan organisasi untuk mencari pekerjaan lain (Colquitt, LePine dan Wesson, 2011). Semakin besar karyawan merasa organisasi tempatnya bekerja mengembangkan kebijakan sumber daya manusia yang berpusat pada kesejahteraan secara profesional, maka semakin kecil kecenderungan karyawan untuk meninggalkan organisasi yang mempekerjakan mereka (Paille, Bordeau \& Galois 2010). Sebuah organisasi yang karyawannya memiliki komitmen organisasi mendapatkan hasil yang diinginkan seperti kinerja tinggi, tingkat pergantian karyawan yang rendah, dan tingkat ketidakhadiran yang rendah. Selain itu juga menghasilkan hasil lain yang diinginkan yaitu iklim organisasi yang hangat, mendukung dan menjadi anggota tim yang baik dan siap membantu (Luthans, 2011). Ada banyak aspek dalam performa kerja yang dianalisis seperti kehadiran kerja, pelaksanaan tugas yang diberikan, dan organizational citizenship behavior (OCB). Beberapa studi yang menguji hubungan antara komitmen organisasi dan kehadiran menyatakan bahwa, affective commitment memiliki hubungan yang positif terhadap kehadiran ketika bekerja (Meyer \& Allen, 1991). Affective commitment memiliki hubungan yang signifikan dengan voluntary absence (Meyer \& Allen, 1991). Sebaliknya, voluntary absence secara signifikan tidak berhubungan terhadap continuance commitment (Gellatly dalam Meyer \& Allen, 1991).
In-role Job Performance, beberapa studi menunjukkan bahwa karyawan dengan komitmen afektif tinggi terhadap organisasi bekerja lebih keras untuk menyelesaikan tugas, dan menunjukan performa yang lebih baik dibandingkan dengan mereka yang komitmen afektifnya rendah (Meyer \& Allen, 1991). Selain itu juga bahwa terdapat hubungan positif antara komitmen afektif dan performa kerja (Baugh \& Roberts dalam Meyer\& Allen, 1991). Namun, beberapa peneliti menyatakan bahwa tidak terdapat hubungan yang signifikan antara continuance commitment dan beberapa pengukuran performa kerja (Angle \& Lawson, dalam Meyer \& Allen, 1991). Citizenship Behavior, Citizenship atau extra-role, diukur dengan menilai beberapa indikator seperti bersedia untuk membantu pekerjaan karyawan lain, bersedia melakukan tugas diluar tugas utama, peduli dengan rekan kerja dan pelanggan, tepat waktu, dan memberi saran ketika terjadi masalah. Karyawan yang memiliki komitmen afektif tinggi menunjukkan keinginan yang lebih tinggi untuk ikut serta dalam organizational citizenship behavior (OCB) (Meyer\& Allen, 1991). Berdasarkan hasil meta analisis dari Organ dan Ryan (dalam Meyer \& Allen, 1991) menunjukkan bahwa continuance commitment tidak memiliki hubungan dengan perilaku altruistik.

Kinerja karyawan merupakan faktor utama penentu apakah tujuan organisasi dapat terwujud sesuai misi dan visi dari organisasi tersebut. Istilah kinerja berasal dari kata job performance atau actual performance yang berarti prestasi kerja atau prestasi sesungguhnya yang dicapai oleh seseorang. Karyawan yang memiliki kinerja tinggi merupakan karyawan yang produktif. Sebaliknya, karyawan yang levelnya tidak mencapai standar yang telah ditentukan organisasi dikatakan sebagai karyawan tidak produktif. Kinerja memiliki definisi yang cukup luas, tidak hanya dinyatakan sebagai hasil kerja karyawan tersebut tetapi juga bagaimana proses 
kerja itu sendiri berlangsung.

Bernardin dan Russel (1993), kinerja diartikan sebagai catatan yang dihasilkan dari fungsi suatu pekerjaan tertentu atau kegiatan selama periode waktu tertentu. Kinerja karyawan merupakan perilaku nyata yang ditampilkan setiap orang sebagai prestasi kerja hasil pekerjaan, serta kuantitas dan kualitas dalam penyelesaian tugas secara individual atau kelompok yang mempunyai hubungan kuat dengan tujuan strategis organisasi dan pengukurannya dilakukan dala kurung waktu tertentu. Agar karyawan dapat menujukan kinerja yang sesuai dengan standar perusahaan, maka dibutuhkan manajemen kinerja yang efektif.

Ivancevich (2008) menyatakan bahwa kriteria yang dapat digunakan untuk mengukur kinerja karyawan secara individu yakni kualitas, pengetahuan tentang pekerjaan, kualitas personel, kerjasama, dapat dipercaya, inisiatif. (a) Kuantitas berkaitan dengan hasil jumlah volume kerja yang dapat diselesaikan karyawan dalam kondisi normal dan meliputi ketelitian, kerapihan, dan ketepatan dalam bekerja atau standar mutu yang ditetapkan. (b) Pengetahuan tentang pekerjaan meliputi pengetahuan yang jelas tentang faktorfaktor yang berhubungan dengan tanggung jawab pekerjaannya. (c) Kualitas personel meliputi penampilan, kepribadian, sikap, kepemimpinan, integrasi dan kemampuan sosial. (d) Kerjasama yaitu kerjasama sesama rekan kerja yakni kemampuan dan keinginan untuk bekerja dengan rekan kerja, atasan serta bawahan untuk mencapai tujuan yang telah ditetapkan. (e) Dapat Dipercaya yakni kesadaran akurasi, menjunjung nilai kejujuran, kedisiplinan/tingkat kehadiran dan sebagainya, dan (f) Inisiatif yaitu kesungguhan dalam melaksanakan tugas dan tanggung jawab, meningkatkan hasil kerja serta memiliki keberanian untuk bekerja secara mandiri.

Indikator kinerja memudahkan pengkajian terhadap job performance dari karyawan. Untuk mengukur kinerja dari pegawai, terdapat enam kriteria primer dari Sopiah, (2008, p.182) yang digunakan untuk mengukur prestasi kerja atau kinerja karyawan, yaitu kualitas, kuantitas, timeliness, costeffectiveness, need for supervision, dan interpersonal impact. Karakteristik orang yang berkinerja tinggi adalah memiliki tanggung jawab pribadi, berani mengambil dan menanggung resiko yang dihadapi, memiliki tujuan yang realistis, memiliki rencana kerja yang menyeluruh dan berjuang untuk merealisasi tujuannya, memanfaatkan umpan balik (feed back) yang konkrit dalam seluruh kegiatan kerja yang dilakukannya, dan mencari kesempatan untuk merealisasikan rencana yang telah diprogramkan (Mangkunegara, 2002,p.68). Kim (2014) melakukan penelitian untuk melihat pengaruh work-life balance terhadap afektif komitmen dan in-role performance, dan untuk mengetahui apakah mediasi komitmen afektif berperan untuk menghubungkan worklife balance dan in-role performance. Hasil penelitian menunjukkan tidak ada pengaruh langsung antara work-life balance terhadap in-role performance. Akan tetapi ditemukan bahwa karyawan yang sudah merasakan worklife balance meningkatkan komitmen afektif dan komitmen afektif memiliki pengaruh yang positif terhadap in-role performance. Ketika karyawan merasakan keseimbangan dalam pekerjaan dan kehidupan pribadinya yang didukung oleh perusahaan tempat mereka bekerja, maka terciptalah ikatan emosional dan komitmen afektif para karyawan semakin kuat. Komitmen afektif ini mendorong karyawan untuk berkontribusi kepada peningkatan kinerja organisasi dan peran . Seperti yang dikatakan oleh Zimbardo (1985) bahwa ketika emosi dibangkitkan, emosi mengarah kepada tindakan. Ini memungkinkan ketika karyawan berkomitmen secara afektif kepada organisasi, emosi ini memotivasi perilaku kerja karyawan, pada akhirnya kinerja karyawan dapat meningkat.

$\mathbf{H}_{2}$ : Komitmen afektif berpengaruh terhadap kinerja karyawan. 


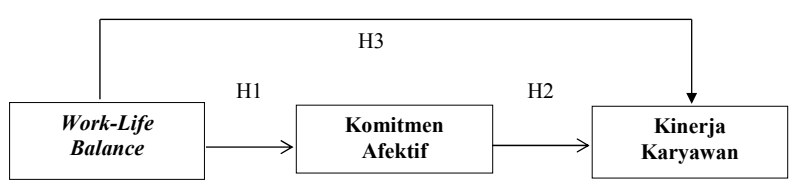

Sumber: Kim, 2014

\section{Gambar 2 Model Penelitian}

Variabel work-life balance dapat memberikan pengaruh langsung terhadap variabel kinerja karyawan, ataupun tidak langsung dengan melalui variabel komitmen afektif terlebih dahulu (variabel intervening). Dalam penelitian ini diuji apakah variabel work-life balance dapat berpengaruh secara langsung atau tidak langsung terhadap kinerja karyawan, dengan variabel komitmen afektif sebagai variabel intervening. Sehingga semakin dapat terlihat apakah dengan adanya work-life balance di organisasi meningkatkan komitmen afektif, dan semakin tinggi komitmen afektif meningkatkan kinerja karyawan di organisasi. Kim (2004), work-life balance memiliki peran yang signifikan dengan psychological well-being dan perilaku kinerja. Work-life balance bersama dengan komitmen afektif dapat mempengaruhi kemajuan kinerja karyawan. Perusahaan membantu karyawan dengan kebijakan dan program work-life balance yang mendukung karyawannya untuk memenuhi tanggung jawab pekerjaan mereka di tempat kerja dan tanggung jawab masing-masing di luar tempat kerja juga agar menumbuhkan ikatan emosional yang menguatkan komitmen afektif karyawan terhadap perusahaan. Sebagai contohnya, perusahaan memberikan program-program worklife balance seperti karyawan diperbolehkan mengunakan ruangan yang sudah disediakan di kantor untuk kegiatan bersama seperti olah raga thai boxing, zumba, dan lain sebagainya, fasilitas pemberian ruang multimedia untuk acara nonton bersama dan makan bersama setiap divisi yang di akomodasi oleh perusahaan, ruang menyusui untuk ibu yang membawa anaknya ke kantor, diizinkan membawa keluarga pada saat acara akhir tahun di acara perusahaan, pemberian santunan untuk karyawan yang mengalami kedukaan dan hadiah untuk orang yang baru menikah, acara gathering yang dilakukan secara rutin setahun sekali untuk pegawai toko dan asuransi kematian untuk karyawan tetap (mortality insurance) yang tidak diberikan oleh perusahaan lain. Programprogram work-life balance tersebut memperkuat komitmen afektif karyawan. Karyawan merasa perusahaan mendukung fleksibilitas karyawan agar bisa menyeimbangkan pekerjaan dan kehidupan pribadi serta perduli tentang kesejahteraan karyawan sehingga secara tidak langsung karyawan merasa perusahaan menjadi bagian penting dari dirinya dan program worklife balance tersebut membantu menumbuhkan psychological well-being yang mampu membuat karyawan untuk menerima dirinya apa adanya (self-acceptance), membentuk hubungan yang hangat dengan orang lain (positive relation with others), memiliki kemandirian dalam menghadapi tekanan sosial (autonomy), mengontrol lingkungan eksternal (environmental mastery), memiliki tujuan dalam hidupnya (purpose in life), serta mampu merealisasikan potensi dirinya secara continue (personal growth) (Ryff, 1989). Dissanayaka \& Ali (2013), menemukan adanya hubungan yang positif dan signifikan antara work-life balance dan kinerja karyawan.

$\mathbf{H}_{3}$ : Work-life balance berpengaruh terhadap kinerja karyawan.

\section{METODE PENELITIAN}

\section{Prosedur Pengambilan Sampel}

Dalam melakukan penelitian penulis melakukan penelitian dengan cara survey, yaitu penulis mengambil sampel dari satu populasi dan menggunakan kuesioner / questionnarie sebagai alat dalam mengumpulkan data pokok. Penelitian ini dilakukan pada perusahaan ritel yang mengkombinasikan 4 aspek penting 
dalam industri bisnis produk gaya hidup, yaitu; toko, distribusi, pelayanan, dan promosi, yang bertempat di Jakarta. Populasi dalam penelitian ini adalah karyawan yang berjumlah 124 karyawan yang tersebar di perusahaan khususnya head office. Jumlah sampel dalam penelitian ini adalah sebanyak 50 orang karyawan, sampel sejumlah 50 orang adalah berdasarkan pada teori Roscoe (Sekaran, 2003) yang menyatakan bahwa pada kebanyakan penelitian jumlah anggota yang ideal dalam sampel penelitian berkisar antara 30 hingga 500 orang. Dalam menentukan calon responden sebagai sampel, pada penelitian ini digunakan convenience sampling yang merupakan bagian dari non-Probability Sampling.

\section{Definisi Operasional dan Pengukuran Variabel}

Work-life balance adalah stressor yang berhubungan dengan pekerjaan yang terdiri dari empat komponen yaitu waktu, energi, pencapaian tujuan, dan ketegangan (Fisher, 2001). Untuk mengukur $W L B$, versi pendek dari kuesioner (checkscale 7) dibuat dan disahkan oleh Daniel dan Bond (2005) menemukan bahwa Checkscale 7 adalah alat ukur yang sesuai untuk memprediksikan skor keseimbangan kerja dan hidup karyawan dilihat dari umur mereka, jenis kelamin, jabatan kerja, dan jam kerja. Indikator pengukuran dalam variabel ini adalah: saya harus membawa pulang pekerjaan ke rumah hampir setiap malam, hubungan saya dengan suami/ istri saya bermasalah dikarenakan oleh tekanan atau jam kerja saya yang panjang, dan saya ingin mengurangi jam kerja dan tingkat stres, tetapi saya merasa tidak punya kontrol atas situasi saat ini.

Komitmen afektif adalah keinginan karyawan untuk tetap tinggal sebagai anggota dari organisasi, keinginan untuk berusaha bagi organisasi, percaya pada nilai-nilai dan normanorma dari organisasi (Glazer \& Kruse, 2008) dan ikatan emosional dengan organisasi (Allen \& Meyer, 1996). Untuk mengukur komitmen afektif pada karyawan indikator pengukuran dalam variabel menggunakan pengukuran yang terdiri dari items 1,2,4,5, dan 6 adalah dari skala komitmen afektif Meyer dan Allen (1997), seperti saya memiliki rasa yang kuat bahwa saya menjadi bagian dari organisasi ini, saya bangga memberitahukan orang lain bahwa saya bekerja di organisasi ini, dan bekerja di organisasi ini memiliki banyak makna pribadi bagi saya.

Kinerja karyawan adalah catatan yang dihasilkan dari fungsi suatu pekerjaan tertentu atau kegiatan selama periode waktu tertentu (Bernardin dan Russel, 1993, p. 135). Alat ukur yang digunakan untuk kinerja karyawan adalah kuesioner kinerja karyawan dikembangkan oleh Tsui; Pearce dan Porter (1997) yaitu kuantitas kerja saya melebihi rata-rata karyawan lain, kemampuan saya melaksanakan pekerjaan utama bagus, dan ketepatan saya dalam melaksanakan pekerjaan bagus.

\section{HASIL PENELITIAN DAN PEMBAHASAN}

Responden dalam penelitian ini terdiri $58 \%$ wanita dan $42 \%$ pria. $64 \%$ responden berusia 20 sampai dengan 30 tahun, 28\% pada usia 31 sampai $40,6 \%$ pada usia 41 sampai 50 tahun, dan sisanya $2 \%$ pada usia 51 sampai 60 tahun. Pendidikan terakhir adalah $62 \%$ adalah lulusan S1, 18\% SMA, 12\% lulusan D1, D2, D3, dan $8 \%$ lulusan S2. Responden yang merupakan karyawan honorer/magang sebesar 4\%, 12\% karyawan kontrak jangka waktu tertentu dan $84 \%$ responden yang merupakan karyawan tetap. Terdapat $84 \%$ responden telah bekerja 1 sampai 5 tahun, $12 \%$ telah bekerja 6 sampai 10 tahun, dan 4\% waktu 11 sampai 15 tahun.

\section{Hasil Uji Reliabilitas}

Suatu kuesioner dikatakan reliable atau handal jika jawaban seseorang terhadap pernyataan adalah konsisten atau stabil dari waktu ke waktu (Ghozali, 2005). Suatu konstruk 
atau variabel dikatakan reliable jika memberikan nilai Cronbach Alpha $>0.60$ (Nunnally dalam Ghozali, 2005, p.133).

\section{Tabel 1}

\section{Hasil Uji Reliabilitas}

\begin{tabular}{|c|c|c|c|}
\hline Variabel & $\begin{array}{c}\text { Cronbach's } \\
\text { Alpha }\end{array}$ & $\begin{array}{c}\text { N of } \\
\text { Items }\end{array}$ & Keterangan \\
\hline Work life balance & 0,843 & 10 & Reliable \\
\hline Komitmen afektif & 0,808 & 6 & Reliable \\
\hline Kinerja karyawan & 0,818 & 10 & Reliable \\
\hline
\end{tabular}

Sumber: hasil olah data

Berdasarkan tabel 1 diketahui bahwa nilai Alpha Cronbach > 0,6 dari semua variabel, maka item-item dalam pertanyaan dapat dinyatakan reliable. Nilai Cronbach's Alpha untuk work-life balance $=0.843$, komitmen afektif $=0.808$, dan kinerja karyawan adalah 0.818 , sehingga dapat dikatakan bahwa keseluruhan item pertanyaan adalah reliable. Sedangkan, indikator kinerja karyawan pada pertanyaan no. 8 dihapuskan karena tidak reliable.

\section{Hasil Uji Validitas}

Suatu kuesioner dikatakan valid jika pertanyaan pada kuesioner mampu untuk mengungkapkan sesuatu yang diukur oleh kuesioner tersebut (Ghozali, 2005, p. 135). Untuk mengukurtingkatvaliditas dapatdilakukan dengan mengkorelasikan antara skor butir pertanyaan dengan total skor konstruk atau variable. Uji validitas dilakukan dengan membandingkan nilai $r$ hitung dengan $r$ tabel untuk tingkat signifikansi $5 \%$ dari degree offreedom $(\mathrm{df})=\mathrm{n}-2$. Dari jumlah sampel yang ada yakni 50 koresponden, degree of freedom $(\mathrm{df})=50-2=48$, dalam hal ini $\mathrm{n}$ adalah jumlah sampel. Jika $r$ hitung yakni 0,284 $>\mathrm{r}$ tabel, maka pertanyaan atau indikator tersebut dinyatakan valid, demikian sebaliknya bila $r$ hitung $<\mathrm{r}$ tabel maka pertanyaan atau indikator tersebut dinyatakan tidak valid (Ghozali, 2005). Tabel 1 menunjukkan bahwa seluruh item pertanyaan valid.
Tabel 2

Hasil Uji Validitas

\begin{tabular}{|c|c|c|}
\hline Item & Nilai $\mathbf{r}$ & Kriteria \\
\hline Work life balance1 & 0.425 & Valid \\
\hline Work life balance 2 & 0.582 & Valid \\
\hline Work life balance3 & 0.453 & Valid \\
\hline Work life balance 4 & 0.403 & Valid \\
\hline Work life balance 5 & 0.622 & Valid \\
\hline Work life balance6 & 0.528 & Valid \\
\hline Work life balance 7 & 0.668 & Valid \\
\hline Work life balance 8 & 0.506 & Valid \\
\hline Work life balance 9 & 0.765 & Valid \\
\hline Work life balance 10 & 0.436 & Valid \\
\hline Komitemen afektif1 & 0.601 & Valid \\
\hline Komitemen afektif 2 & 0.658 & Valid \\
\hline Komitemen afektif3 & 0.635 & Valid \\
\hline Komitemen afektif4 & 0.656 & Valid \\
\hline Komitemen afektif5 & 0.516 & Valid \\
\hline Komitemen afektif6 & 0.555 & Valid \\
\hline Kinerja1 & 0.539 & Valid \\
\hline Kinerja2 & 0.687 & Valid \\
\hline Kinerja3 & 0.517 & Valid \\
\hline Kinerja4 & 0.615 & Valid \\
\hline Kinerja5 & 0.466 & Valid \\
\hline Kinerja6 & 0.527 & Valid \\
\hline Kinerja7 & 0.356 & Valid \\
\hline Kinerja9 & 0.409 & Valid \\
\hline Kinerja10 & 0.439 & Valid \\
\hline Kinerja11 & 0.557 & Valid \\
\hline
\end{tabular}

Sumber: hasil olah data

\section{Hasil Pengujian Hipotesis}

Pengujian hipotesis 1 dilakukan dengan menggunakan model mediasi (dua jalur) dalam analisis jalur path (path analysis). Metode analisis jalur merupakan perluasan dari analisis regresi berganda, atau analisis jalur adalah penggunaan analisis regresi untuk menaksirkan hubungan antara variabel yang telah ditetapkan sebelumnya berdasarkan teori (Ghozali, 2005). Tujuannya adalah menerangkan akibat langsung dan tidak langsung seperangkat variabel, sebagai variabel penyebab, terhadap variabel lainnya 
yang merupakan variabel akibat. Model yang digunakan dalam analisis jalur:

$$
\begin{aligned}
& \mathrm{Y}_{1}=\alpha+\mathrm{P} 2 \mathrm{X}+\varepsilon 1 \\
& \mathrm{Y}_{2}=\alpha+\mathrm{P} 1 \mathrm{X}+\mathrm{P} 3 \mathrm{Y} 2+\varepsilon 2
\end{aligned}
$$

\section{Koefisien Korelasi}

Dari tabel 2 dapat diketahui bahwa nilai koefisien korelasi (r) untuk work life balance dengan komitmen afektif adalah sebesar 0,376, work life balance dengan Kinerja karyawan 0.535 dan komitmen afektif dengan Kinerja karyawan 0.493 . Nilai probabilitas yang diperoleh dilihat dari sig (2-tailed) adalah di bawah 0.05, menunjukkan bahwa hubungan atau korelasi tiap variabel adalah signifikan.

Tabel 3

\section{Koefisien Korelasi}

\begin{tabular}{|c|c|c|c|c|}
\hline & & $\begin{array}{l}\text { total } \\
\text { work life } \\
\text { balance }\end{array}$ & $\begin{array}{l}\text { total } \\
\text { komitmen } \\
\text { afektif }\end{array}$ & $\begin{array}{l}\text { total kinerja } \\
\text { karyawan }\end{array}$ \\
\hline $\begin{array}{l}\text { total } \\
\text { work life }\end{array}$ & $\begin{array}{l}\text { Pearson } \\
\text { Correlation }\end{array}$ & 1 & $.376^{* *}$ & $.535^{* *}$ \\
\hline balance & Sig. (2-tailed) & & .007 & .000 \\
\hline & $\mathrm{N}$ & 50 & 50 & 50 \\
\hline $\begin{array}{l}\text { total } \\
\text { komitmen }\end{array}$ & $\begin{array}{l}\text { Pearson } \\
\text { Correlation }\end{array}$ & $.376^{* *}$ & 1 & $.493^{* *}$ \\
\hline & Sig. (2-tailed) & .007 & & .000 \\
\hline & $\mathrm{N}$ & 50 & 50 & 50 \\
\hline $\begin{array}{l}\text { total } \\
\text { kinerja }\end{array}$ & $\begin{array}{l}\text { Pearson } \\
\text { Correlation }\end{array}$ & $.535^{* *}$ & $.493^{* *}$ & 1 \\
\hline karyawan & Sig. (2-tailed) & .000 & .000 & \\
\hline & $\mathrm{N}$ & 50 & 50 & 50 \\
\hline
\end{tabular}

Correlations

**. Correlation is significant at the 0.01 level (2-tailed) Sumber: hasil olah data

\section{Koefisien Regresi}

Koefisien regresi dalam model persamaan I (pengaruh secara langsung work life balance terhadap komitmen afektif).

Dari hasiloutput spss model summary pada tabel 3 menunjukkan jumlah variance variable lain yang tidak ditentukan dan dijelaskan oleh variabel work life balance yang besar nilainya adalah: $P \varepsilon_{1}=\sqrt{ }\left(1-R^{2}\right)=\sqrt{ }(1-0,141)=0,9269$.

Tabel 4

Model Summary Persamaan I

Model Summary

\begin{tabular}{|l|l|l|l|l|}
\hline Model & $\mathrm{R}$ & R Square & $\begin{array}{l}\text { Adjusted } \\
\text { R Square }\end{array}$ & $\begin{array}{c}\text { Std. Error } \\
\text { of the } \\
\text { Estimate }\end{array}$ \\
\hline 1 & $.376^{\mathrm{a}}$ & .141 & .123 & 2.826 \\
\hline
\end{tabular}

a. Predictors: (Constant), total work life balance Sumber: hasil olah data

Pada tabel 4 dapat diketahui bahwa nilai standardized coefficients beta work life balance adalah sebesar 0.376, angkat tersebut merupakan nilai path atau jalur P2 dan memiliki nilai sig $0,007<0,05$ sehingga work life balance berpengaruh secara signifikan terhadap komitmen afektif.

Tabel 5

\section{Koefisien Regresi Persamaan I}

Coefficients
\begin{tabular}{|l|l|l|l|l|l|l|}
\hline \multirow{2}{*}{$\begin{array}{l}\text { Model } \\
\text { B }\end{array}$} & $\begin{array}{l}\text { Standardized } \\
\text { Coefficients }\end{array}$ & \multicolumn{1}{l|}{$\begin{array}{l}\text { Standardized } \\
\text { Coefficients }\end{array}$} & & \\
\cline { 3 - 6 } & & Std. Error & Beta & & \multirow{2}{*}{ Sig. } \\
\hline 1 & (Constant) & 17.081 & 2.039 & & 8.377 & .000 \\
\cline { 2 - 6 } & total work life balance & .162 & .058 & .376 & 2.811 & .007 \\
\hline
\end{tabular}

a. Dependent Variable: total komitmen afektif Sumber: hasil olah data

Koefisien regresi dalam model persamaan II (pengaruh secara langsung work life balance dan komitmen afektif terhadap Kinerja Karyawan).

Tabel 6

Model Summary Persamaan II

Model Summary

\begin{tabular}{|l|c|l|l|l|}
\hline Model & $\mathrm{R}$ & R Square & $\begin{array}{c}\text { Adjusted R } \\
\text { Square }\end{array}$ & $\begin{array}{c}\text { Std. Error of the } \\
\text { Estimate }\end{array}$ \\
\hline 1 & $.620^{\mathrm{a}}$ & .385 & .359 & 3.164 \\
\hline
\end{tabular}

a. Predictors: (Constant), total komitmen afektif, total work life balance

Sumber: hasil olah data

Tabel 5 menunjukkan jumlah variance variable lain yang tidak ditentukan dan dijelaskan 
oleh variabel work life balance yang besar nilainya adalah: $P \varepsilon_{2}=\sqrt{ }\left(1-R^{2}\right)=\sqrt{ }(1-0,385)=$ 0,7842 .

\section{Tabel 7}

\section{Koefisien Regresi Persamaan II}

\begin{tabular}{|c|c|c|c|c|c|c|}
\hline \multicolumn{7}{|c|}{ Coefficients $^{\mathrm{a}}$} \\
\hline \multirow{2}{*}{\multicolumn{2}{|c|}{$\begin{array}{l}\text { Model } \\
\text { B }\end{array}$}} & \multicolumn{2}{|c|}{$\begin{array}{l}\text { Standardized } \\
\text { Coefficients }\end{array}$} & \multirow[t]{2}{*}{$\begin{array}{l}\text { Standardized } \\
\text { Coefficients }\end{array}$} & \multirow[b]{2}{*}{$\mathrm{t}$} & \multirow[b]{2}{*}{ Sig. } \\
\hline & & Std. Error & Beta & & & \\
\hline \multirow[t]{3}{*}{1} & (Constant) & 23.603 & 3.582 & & 6.590 & .000 \\
\hline & total work life balance & .229 & .070 & .407 & 3.299 & .002 \\
\hline & total komitmen afektif & .444 & .162 & .339 & 2.750 & .008 \\
\hline
\end{tabular}

a.Dependent Variable: total kinerja karyawan

Sumber: hasil olah data

Tabel 7 diketahui bahwa nilai standardized coefficients beta work life balance adalah 0.407 dengan nilai sig $0.002<0.05$ yang merupakan jalur P1 dan komitmen afektif sebesar 0.339 dengan nilai sig $0.008<0.05$ yang merupakan jalur P3. Hasil analisis jalur menunjukan bahwa work life balance dapat berpengaruh langsung terhadap kinerja karyawan dan juga berpengaruh tidak langsung yaitu dari work life balance melalui komitmen afektif sebagai variabel intervening kepada kinerja karyawan. Besarnya pengaruh langsung adalah 0.229 , sedangkan pengaruh tidak langsung yaitu $\mathrm{P}_{2} \mathrm{X}_{3}=0.376 \times 0.339=0.127$. Maka total pengaruh work life balance terhadap kinerja karyawan yakni: $\mathrm{P}_{1}+\left(\mathrm{P}_{2} \mathrm{X} \mathrm{P}_{3}\right)=0.407+($ $0.376 \times 0.339)=0.534$.

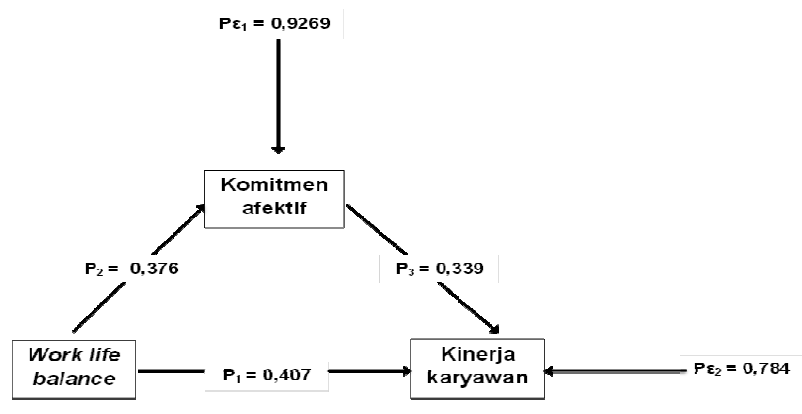

Gambar 3

Hasil Interpretasi Analisis Jalur
Dari perhitungan diatas dapat diketahui bahwa work life balance tidak berpengaruh secara signifikan terhadap kinerja karyawan melalui komitmen afektif dengan nilai $\mathrm{P}_{2} \mathrm{X}_{3}<\mathrm{P}_{1}$ yakni $0.127<0.407$ sehingga dapat disimpulkan bahwa komitmen afektif bukan merupakan mediator dalam hubungan antara work life balance terhadap kinerja karyawan. Hal ini menunjukkan bahwa pengaruh yang sebenarnya antara work life balance terhadap kinerja karyawan adalah pengaruh langsung.

Berdasarkan hasil analisis data di atas, dapat diketahui bahwa karakteristik responden yang berjenis kelamin laki-laki sebanyak 21 orang dan wanita sebanyak 29 orang dengan usia mayoritas 21-30 tahun. Sebanyak 84\% dari responden memiliki pendidikan terakhir S1 dan telah bekerja selama satu sampai dengan lima tahun. Dari tabel model summary pada persamaan I dapat diketahui bahwa nilai Adjusted R-Square adalah sebesar 0.123 , ini menunjukkan bahwa kontribusi variasi nilai work life balance dalam mempengaruhi variasi nilai komitmen afektif adalah sebesar $12.3 \%$, sisanya sebesar $87.7 \%$ merupakan kontribusi variabel lain yang tidak diikutsertakan di dalam model penelitian ini. Dari tabel model summary pada persamaan II dapat diketahui bahwa nilai Adjusted R-Square adalah sebesar 0.359, menunjukkan bahwa kontribusi variasi nilai work life balance dan komitmen afektif dalam mempengaruhi variasi nilai kinerja karyawan adalah sebesar $35.9 \%$, sisanya $64.1 \%$ merupakan kontribusi variabel lain yang tidak diikutsertakan di dalam model penelitian ini.

Dari hasil uji hipotesis diketahui bahwa variabel work life balance memiliki pengaruh yang signifikan terhadap komitmen afektif dan kinerja karyawan. Variabel komitmen afektif memiliki pengaruh signifikan terhadap kinerja karyawan. Hal ini terlihat dari nilai sig. variabelvariabel tersebut lebih kecil dari $\alpha=0,05$. Artinya, variabel work life balance dan komitmen afektif berpengaruh secara kuat terhadap kinerja 
karyawan di PT Time International. Dari hasil perhitungan nilai koefisien yang dihasilkan, variabel work life balance tidak berpengaruh signifikan terhadap kinerja karyawan melalui komitmen afektif. work life balance melalui komitmen afektif tidak berpengaruh secara signifikan terhadap kinerja karyawan dan komitmen afektif bukan merupakan mediator yang kuat dalam memediasi hubungan antara work life balance terhadap kinerja karyawan dan pengaruh yang sebenarnya antara work life balance terhadap kinerja karyawan adalah pengaruh langsung dan temuan dari penelitian ini dapat disimpulkan bahwa komitmen afektif ternyata berperan sebagai variabel independen, bukan variabel mediasi.

Dari hasil penelitian sebelumnya yang dilakukan oleh Kim (2014) bahwa komitmen afektif secara signifikan memediasi hubungan antara work life balance dan in role performance. Komitmen afektif pada karyawan meningkat berdasarkan pengalaman dari work life balance mempunyai dampak positif kepada peningkatan performa karyawan dalam hal in roleperformance. Bila perusahaan dapat mengolah sumber daya dengan baik, maka karyawan menjalankan peran di perusahaan dengan baik sehingga kinerja karyawan meningkat dan tujuan perusahaan dapat terealisasi. Penelitian oleh Kim berbeda dengan hasil penelitian ini yang menunjukan bahwa komitmen afektif bukan variabel mediasi untuk hubungan antara work life balance dengan kinerja karyawan. Hal ini dapat disebabkan karena beberapa faktor, contohnya: sampel dan jumlah sampel penelitian yang berbeda dimana pada penelitian Kim sampel yang digunakan sebanyak 293 responden dimana jawaban dari sampel lebih bervariasi dibandingkan dengan penelitian ini. Kedua, pada penelitian ini juga hanya melihat komitmen afektif dari karyawan, terlihat bahwa komitmen afektif tinggi, akan tetapi $84 \%$ dari koresponden memiliki rentan waktu kerja dikisaran 1-5 tahun dimana pada rentan waktu 1-5 tahun ikatan emosional antara karyawan dengan perusahaan belum sangat dirasakan. Bila karyawan memiliki masa kerja yang panjang maka karyawan tersebut merasa nyaman untuk tetap tinggal di dalam organisasi tersebut karena sudah memiliki hubungan emosional sehingga terciptanya komitmen organisasi. Hal ini dibuktikan dengan penelitian empiris yang dilakukan oleh Kalbers dan Cenker (2007) terhadap 334 akuntan yang bekerja di beberapa kota metropolitan di Amerika Serikat menunjukkan bahwa pengalaman kerja (masa kerja) berpengaruh positif dan signifikan terhadap komitmen organisasional "Auditors with more experience have less role ambiguity, have more affection for their organization, and are less inclined to leave their organization". Berdasarkan penjelasan dan bukti empiris tersebut ini maka dapat disimpulkan bahwa masa kerja berpengaruh positif terhadap komitmen organisasi.

\section{KESIMPULAN DAN SARAN}

\section{Kesimpulan}

Setelah melakukan penelitian dan pengkajian data yang didapat dari responden serta membandingkan dengan teori yang ada, penulis dapat mengambil simpulan dari penelitian pengaruh work-life balance terhadap kinerja karyawan yang dimediasi oleh komitmen afektif. Berdasarkan hasil path analysis, work-life balance berpengaruh terhadap komitmen afektif, komitmen afektif berpengaruh terhadap kinerja karyawan dan work balance-life berpengaruh terhadap kinerja karyawan. Komitmen afektif bukan merupakan mediator atau intervening yang kuat dalam memediasi hubungan antara worklife balance terhadap kinerja karyawan karena pengaruh langsung lebih besar dibandingkan pengaruh tidak langsung.

Keterbatasan dalam penelitian ini adalah responden menjawab pertanyaan kuesioner 
mengenai variabel kinerja yang diisi sendiri oleh karyawan bagaimana kinerja mereka (selfreporting), sehingga sangat mungkin terjadi common method bias. Selain itu, subjektifitas responden berpotensi untuk memunculkan perceptual bias.

Implikasi penelitian ini bagi perusahaan adalah perusahaan perlu mempertahankan dan juga menambahkan pemberian fasilitas untuk program-program work-life balance yang ada saat ini, contohnya perusahaan dapat menyediakan program salah satunya Happy Friday yakni karyawan dapat meninggalkan kantor dua jam lebih awal disetiap hari jumat di minggu terakhir setiap bulannya dan refreshing day-offs yakni para pekerja mengambil dua minggu cuti setiap tiga tahun untuk menyegarkan kembali pikiran dan mempunyai waktu yang berkualitas bersama keluarga. Keuntungan dari program-program tersebut dapat mempengaruhi karyawan secara emosional dan persepsi bahwa mereka akan merasa bahwa organisasi mendukung dengan perduli terhadap kesejahteraan karyawan seperti dikatakan oleh Kim (2014).

\section{Saran}

Manajemen perusahaan sebaiknya memberikan dukungan penuh kepada programprogram tersebut sehingga seluruh karyawan merasa nyaman untuk menggunakan programprogram tersebut kapanpun mereka butuhkan dan memiliki tempat untuk karyawan dapat berkomunikasi dengan perusahaan agar karyawan merasa perusahaan perduli dengan kehidupan pribadikaryawan(Kim, 2014). Variabel komitmen afektif pada penelitian ini tidak memediasi, sehingga dalam penelitian selanjutnya variabel komitmen afektif dapat dijadikan variabel independen. Bagi peneliti selanjutnya, pemilihan indikator sebagai alat ukur variabel hendaknya lebih diperbanyak dan divariasikan sesuai dengan kondisi yang ada pada obyek penelitian misalnya dengan menggunakan seluruh aspek dari komitmen organisasional yakni komitmen afektif, komitmen berkelanjutan (continuance), dan komitmen normatif. Menambahkan jumlah sampel penelitian sehingga variasi data pada penelitian dan keakuratan hasil penelitian meningkat.

\section{DAFTAR PUSTAKA}

Allen, N.J., \& Meyer, J.P. (1990). The measurement and antecedents of affective, continuance and normative commitment to the organization, Journal of Occupational Psychology, Vol. 63 (1), 1-18.

Allen, N.J., \& Meyer, J.P. (1996). Affective, continuance, and normative commitment to the organization: An examination of construct validity, Journal of Vocational Behavior, Vol. 49 (3), 252-276.

Bernardin, H. John., \& Russel, E.A. (1993). Human resource Management, An Experiential Approach. Mc. Graw Hill International Edition, Singapore: Mac Graw Hill Book Co.

Byrne, U. (2005). Work-Life balance: Why are we talking about it at all?, Business Information Review, Vol.22 (1), 53-59.

Cherrington, D.J. (1994). Organisational Behaviour, (2 ${ }^{\text {nd }}$ ed.). Boston, U.S: Allyn and Bacon, Inc.

Clark, S.C. (2000). Work/family border theory: A new theory of work/family balance, Human Relations, Vol. 53 (6), 747-770.

Colquitt, J., LePine, J., \& Wesson, M. (2009). Organizational Behavior: Essentials for Improving Performance and Commitment $\left(1^{\text {st }}\right.$ ed.). New York: The McGraw-Hill Companies Inc.

Colquitt, J., LePine, J., \& Wesson, M. (2009). Organizational Behavior: Improving Performance and Commitment in the 
Workplace (1 ${ }^{\text {st }}$ ed.). New York: The McGraw-Hill Companies Inc.

Daniels, L., \& McCarraher, L. (2000). The WorkLife Manual. Industrial Society. London.

Fisher, M. (2001). Work/personal life balance: A construct development study, Dissertation Abstracts International

Fuad, M. (2004). Survai Diagnosis Organisasional Konsep \& Aplikasi. Semarang: Universitas Diponegoro.

Frone, M.R. (2003). Work-Family Balance, in Handbook of Occupational Health Psychology, eds. J.C. Quick and L.E. Tetrick, Washington, DC: American Psychological Association, 143-162.

Geurts, S.A.E. \& Demerouti, E. (2003). Work/ non-work interface: A review of theories and findings. In M.J. Schabracq, J.A.M. Winnubst \& C.L. Cooper (Eds.). The handbook of work and health psychology. Chichester, England: John Wiley \& Sons, 279-312

Ghozali, I. (2005). Aplikasi Analisis Multivariate dengan Program SPSS. Semarang: Universitas Diponegoro

Glazer, S. \& Kruse, B. (2008). "The role of organizational commitment in occupational stress models", International Journal of Stress Management, Vol. 15 (4), 329-344.

Greenhaus, J.H., \& Powell, G.N. (2006). When Work and Family Are Allies: ATheory of Work-Family Enrichment. Academy of Management Review, Vol. 31(1), 72-92.

Guest, D. E. (2002). "Perspectives on the Study of Work-Life Balance", Social Science Information, 41 (2): 255-279.

Hammer, L.B., Neal, M.B., Newson, J.T., Brockwood, K.J. \& Colton, C.L. (2005). A longitudinal study of the effects of dual-earner couples' utilization of family-friendly workplace supports on work and family outcomes, Journal of Applied Psychology, Vol. 90 (4), 799810.

Harrington, B., \& Ladge, J. (2009). "Present dynamics and future directions for organizations", Organizational Dynamics, Vol. 38 (2), 148-157.

Ivancevich, J. M., Konopaske, R., Matteson, M. T. (2008). Organizational behavior and management. ( $8^{\text {th }}$ ed.). New York: The McGraw-Hill Companies Inc.

Kalliath, T., \& Brough, P. (2008a). Editorial: Achieving work-life balance. Journal of Management \& Organization 14(3), 224-226.

Kim, H.K. (2014). "Work-life balance and employees' performance: the mediating role of Affective Commitment", Global Business and Management Research: An International Journal, Vol.6 (1), 37 51.

Luthans, F. (2011). Organizational behavior: an evidence-based approach. (12 $2^{\text {th }}$ ed.). New York: Mcgraw Hill- Irwin.

Mangkunegara, A. N. (2002). Manajemen Sumber Daya Manusia. Bandung: Remaja Rosdakarya.

Mathis R. L., Jackson, J. H. (2003). Human Resources Management. Ohio: Thomson /South-western

Mathis R. L., Jackson, J. H. (2011). Human Resources Management $\left(10^{\text {th }} e d\right.$.). Jakarta: Salemba Empat.

Meyer, J. P., \& Allen, N. J. (1991). A three-component conceptualization of organizational commitment.Resource Management Review, Vol. 1, 61-89. The University of Western, Ontario: Canada

Meyer, J. P., \& Allen, N. J. (1997). “Commitment in the workplace: Theory, research, and application”. Sage: Thousand Oaks. 
Mowday, R. T., Steers, R. M., \& Porter, L. W. (1979). The measurement of organizational commitment. Journal of Vocational Behavior, (14), 224-247.

Muse, L., Harris, S.G., Giles, W.F., \& Feild, H.S. (2008). Work-life benefits and positive organizational behavior: Is there a connection?, Journal of Organizational Behavior, Vol. 29 (2), 171-192.

Noe, R. A., Hollenbeck, J. R., Gerhart. B., \& Wright, P. M. (2000). Human Resource Management: Gaining A Competitive Advantage $\quad\left(3^{\text {rd }}\right.$ ed.). Boston:The McGraw Hill- Irwin Company Inc.

Price, A. (2007). Human Resource Management in a Business Context ( $3^{\text {rd }}$ ed.). London: Thomson

Rivai, V. (2004). Manajemen Sumber Daya Manusia Untuk Perusahaan,

Cetakan Pertama. Jakarta: PT. Raja Grafindo.

Robbins, S. P., \& Timothy A. J. (2007). Perilaku Organisasi, Buku 1 dan 2. Jakarta: Salemba Empat.
Robbins, S. P., \& Timothy A. J. (2008). Perilaku Organisasi $\left(12^{\text {th }}\right.$ ed.). Jakarta: Salemba Empat.

Sandjojo, Nidjo. 2011. Metode Analisis Jalur dan Aplikasinya. Jakarta: Pustaka Sinar Harapan

Schabracq, M.J., Winnubst, J.A.M., \& Cooper, C.L. (2003), The Handbook of Work and Health Psychology. Chichester, England: John Wiley \& Sons, 279-312

Schermerhorn Jr, J. R., Osborn, R. N., Uhl-Bien, M., Hunt, J. G. (2011). Organizational Behavior (12 ${ }^{\text {th }}$ ed.). USA: John Wiley \& Sons.

Sopiah. (2008). Perilaku Organisasional. Yogyakarta : C.V Andi Offset.

Sugiyono. (2003). Metode Penelitian Bisnis. Bandung. Pusat Bahasa Depdiknas.

Thornthwaite, L. (2004), "Working time and work-family balance: A review of employees' preferences", Asia Pacific Journal of Human Resources, Vol.42 (2), 166-184. 